\title{
Efek Beta Karoten dan Agregasi Klorofil Pada Fotostabilitas KIorofil a dalam Pelarut Aseton
}

\author{
Junet. F. da Costa ${ }^{1^{*}}$, Ferry F. Karwur ${ }^{2,3)}$, dan Leenawaty Limantara ${ }^{2,4)}$ \\ 1)PT. Wacana Tata Akademika JI Cilandak Tengah II No.3A, Jakarta 12430 \\ ${ }^{2}$ Magister Biologi Universitas Kristen Satyawacana \\ ${ }^{3}$ Fakultas Biologi Universitas Kristen Satya Wacana \\ Jl. Diponegoro No. 52-60 Salatiga 50711, Telp. (0298)321212, ext 305, Fax. (298)321433 \\ ${ }^{4} \mathrm{Ma}$ Chung Research Centre, Universitas Ma Chung, Malang 65151
}

Diterima 23-05-2008 Disetujui 21-02-2009

\begin{abstract}
Chlorophyll as photosynthetic pigment has many benefits to human such as antioxidant, antibacterial, color additive, immunity, and photosensitizer. Concerning to these applications, chlorophyll $a$ will react with oxygen and light and reduce its effectiveness. It is then important to understand the stability of chlorophyll $a$ on oxygen and light. Stability of chlorophyll $a$ in the presence of beta-carotene (1:1) in acetone was studied for various water concentrations. Each solution was exposed to red light (ë e" $630 \mathrm{~nm})$ for $0.5 ; 1.0 ; 2.5 ; 5.0 ; 10 ; 20 ; 30 ; 40 ; 50$; and 60 minutes and their spectrum were analysed. When water was added $(8.33 ; 16.67 ; 25 ; 33.33 ; 41.67 ; 50 ; 58.33 ; 66.67$; 75; and 83.33 percent) to the acetone solution of chlorophyll $a$, the chlorophylls aggregate, and in the presence of beta-carotene, the chlorophyll more stable. The water shifts the chlorophyll $a$ spectrum toward red during illumination with or without the presence of carotene. The formation of oligomeric chlorophyll $a$ aggregate occurs within 10-20 minutes after the water was applied. This strategy of aggregating the chlorophylls to dissipate excess energy captured from light does not support the photostability of chlorophyll as much as beta-carotene. Surprisingly, when beta carotene was mixed with $66.7 \%$ and $75.0 \%$ of water, the chlorophyll $a$ degraded $5.56 \%$ and $9.71 \%$ respectively. In conclusion, the aggregate form of chlorophyll $a$ and the presence of beta-carotene increase photostability of chlorophyll $a$ in acetone solution.
\end{abstract}

Keywords: aggregation, beta carotene, chlorophyll a, photostability.

\section{PENDAHULUAN}

Klorofil merupakan pigmen yang berperan dalam proses fotosintesis yang banyak ditemukan pada tumbuhan tingkat tinggi, pakis, lumut, alga, dan organisme prokariota, terdiri dari klorofil $a$ sebagai pigmen utama dan klorofil $b$ sebagai pigmen pelengkap (Gross 1987; Lichtenthaler 1987; Gross 1991; Scheer 1991 2006). Semua organisme yang menghasilkan oksigen melalui proses fotosintesis pasti memiliki klorofil $a$ (Katz et al, 1978b), yang umumnya terdapat paling banyak pada komplek antena tumbuhan tingkat tinggi (Vladkova 2000).

Dalam menjalankan fungsinya, klorofil dibantu oleh karotenoid yang menyerap cahaya pada daerah yang tidak diserap oleh molekul klorofil, kemudian mentransfer energi cahaya tersebut melalui tahapan singlet-singlet kepada klorofil (Gross 1991; Barzda et

*Telp: 0298321212

Email: junetdacosta@yahoo.com al, 1998; Wang et al, 2004). Disamping memanen cahaya, karotenoid juga memiliki peran ganda lain yakni melindungi klorofil dari energi cahaya berlebihan, serta memburu dan memadamkan oksigen singlet yang membahayakan molekul klorofil bahkan sel (Zurdo et al, 1992; Britton et al, 1995; Jeffrey et al, 1997; Barzda et al, 1998; Fiedor et al, 2001; Wang et al, 2004; Scheer 2006).

Selain berperan penting dalam lingkungan aslinya, klorofil memiliki manfaat penting bagi kehidupan manusia. Sifat biokimia dan fotokimia klorofil memberikan kontribusi yang besar terutama dalam bidang kesehatan dan pangan, antara lain penambah sel darah merah, antioksidan, antibakteria, meningkatkan imunitas, pengganti sel-sel yang rusak, pewarna, dan lain-lain, termasuk yang sekarang banyak diteliti sebagai fotosensitizer generasi baru dalam terapi fotodinamika terhadap tumor/kanker. Dalam aplikasinya, klorofil akan berinteraksi dengan dua komponen penting yakni oksigen dan cahaya (Fiedor et al, 2002). Pada saat cahaya yang diterima sangat berlebihan, klorofil yang tereksitasi oleh energi yang 
besar akan melakukan lompatan ke tahapan triplet sehingga mudah untuk mentransfer energinya ke molekul oksigen sehingga terbentuk oksigen singlet yang membahayakan klorofil, bahkan komplek protein maupun sel di lingkungan aslinya (Abeliovich \& Shilo 1972). Seringkali dalam kondisi cahaya berlebihan, klorofil membentuk agregat dengan perantaraan molekul air (Vladkova 2000). Oleh karena itu, stabilitas klorofil terhadap oksigen dan cahaya menjadi faktor penting.

Beberapa penelitian telah dilakukan untuk menguji fotostabilitas klorofil $a$ dengan pengaruh pelarut, karotenoid, dan agregasi klorofil, antara lain oleh Anderson and Calvin (1964), de Paula et al, (1995), Vladkova (2000), Fiedor et al, (2001; 2002), dan Agostiano et al, (2003), tetapi dilakukan secara terpisah-pisah, sedangkan kombinasi pengaruh karotenoid dan agregasi sekaligus terhadap fotostabilitas klorofil $a$ belum dipelajari. Oleh karena itu, penelitian ini bertujuan untuk melihat sejauh mana pengaruh konsentrasi air terhadap proses agregasi yang terbentuk sehingga klorofil $a$ mampu mempertahankan dirinya dari kerusakan melalui pelepasan energi antar molekul klorofil $a$, dan seberapa besar pengaruh dari kombinasi beta karoten dan agregasi terhadap fotostabilitas klorofil $a$.

\section{BAHAN DAN METODE}

Bahan. Sumber pigmen klorofil a diambil dari daun suji (Pleomelle angustifolia) dan beta karoten diekstrak dari wortel (Daucus carota L.). Bahan-bahan lain yang digunakan adalah larutan aseton, dietil eter, heksana, metanol, akuades, $\mathrm{CaCO}_{3}, \mathrm{Na}_{2} \mathrm{SO}_{4}$ anhidrat, silika gel 60 , pelat KLT silika gel $60 \mathrm{~F}_{254}$ (Merck), gas $\mathrm{N}_{2}$ dan garam dapur.

Metode. Ekstraksi pigmen. Daun suji diekstrak menggunakan pelarut aseton:metanol $3: 7(\mathrm{v} / \mathrm{v})$, sedangkan wortel dengan pelarut yang sama tapi dengan perbandingan $7: 3(\mathrm{v} / \mathrm{v})$. Masing-masing ekstrak disaring dan residunya dilarutkan kembali dengan pelarut yang sama sampai semua pigmen terangkat. Filtrat masing-masing ekstrak dipartisi secara terpisah menggunakan dietil eter dengan perbandingan $1: 1$ (v/v), yang dapat dikombinasikan dengan akuades dan larutan garam dapur jenuh (jika larutan pigmen sulit terpisah). Lapisan eter yang mengandung pigmen (berwarna) diambil kemudian ditambahkan $\mathrm{Na}_{2} \mathrm{SO}_{4}$ anhidrat supaya mengikat $\mathrm{H}_{2} \mathrm{O}$, lalu disaring. Filtrat masing-masing ekstrak dipekatkan dengan rotary evaporator, lalu dikeringkan dengan gas $\mathrm{N}_{2}$.

Kromatografi kolom. Kolom kromatografi disiapkan dengan fase diam silika gel 60 yang dilarutkan dalam campuran fase gerak heksana : dietil eter : aseton ( $60: 30: 20 \mathrm{v} / \mathrm{v})$ untuk mengelusi ekstrak daun suji, dan heksana 100\% untuk ekstrak wortel. Ekstrak kasar masing-masing sampel dilarutkan dalam heksana dan dielusi dengan fase gerak masing-masing. Pita hijau biru (klorofil $a$ ) dikoleksi dari kolom ekstrak daun suji, sedangkan dari kolom ekstrak wortel dikoleksi pita kuning-orange (beta karoten). Masing-masing pigmen ditampung kemudian dikeringkan dengan gas $\mathrm{N}_{2}$ secepatnya.

Kemurnian Isolat Pigmen. Ekstrak kasar masing-masing sampel dan isolat yang dikoleksi dari kolom kromatografi dilarutkan dalam heksana (ekstrak kasar wortel dan beta karoten) dan aseton (ekstrak kasar daun suji dan klorofil a) secara terpisah, kemudian masing-masing diambil sebanyak 10ì L lalu ditotolkan pada pelat KLT silika gel $60 \mathrm{~F}_{254}$ (Merck). Pelat KLT yang telah ditotolkan masing-masing sampel dielusi dengan fase gerak yang berbeda seperti pada kromatografi kolom. Nilai $R_{f}$ masing-masing isolat dihitung dan dibandingkan dengan ekstrak kasarnya. Isolat klorofil $a$ dan beta karoten juga diuji pola spektranya dalam aseton menggunakan spektrofotometer berkas rangkap Varian Cary 50 pada panjang gelombang 350-800 nm. Pola spektra masingmasing pigmen dibandingkan dengan pola spektra literatur (Jeffrey et al, 1997).

Penetapan Konsentrasi Molar Pigmen. Klorofil a dan beta karoten dilarutkan dalam $3 \mathrm{~mL}$ aseton secara terpisah, kemudian penentuan konsentrasi klorofil a diukur pada ë max $662.7\left(a ̊=78.75 \times 10^{3} \mathrm{~L} \mathrm{~mol}^{-1} \mathrm{~cm}^{-1}\right.$ dalam aseton), sedangkan konsentrasi beta karoten diukur pada ë max $454\left(\stackrel{a}{=}=134 \times 10^{3} \mathrm{~L} \mathrm{~mol}^{-1} \mathrm{~cm}^{-1}\right.$ dalam aseton) (Jeffrey et al, 1997).

IIrradiasi Klorofil $a$, dan campuran klorofil $a$ dengan beta karoten. Klorofil $a$ dilarutkan dalam aseton, kemudian ditambahi dengan akuades masingmasing sebanyak $8.33 \% ; 16.67 \%$; 33.33\%; 41.67\%; $50 \%$; 58.33\%; 67.67\%; 75\%; dan $83.33 \% \mathrm{~mL}$ hingga volume akhir campuran mencapai $3 \mathrm{~mL}$. Setiap campuran dimasukan dalam kuvet yang diberi magnetic stirer untuk menghomogenkan campuran, selanjutnya diiradiasi dengan lampu volpi (intralux 610) daylight 
a)

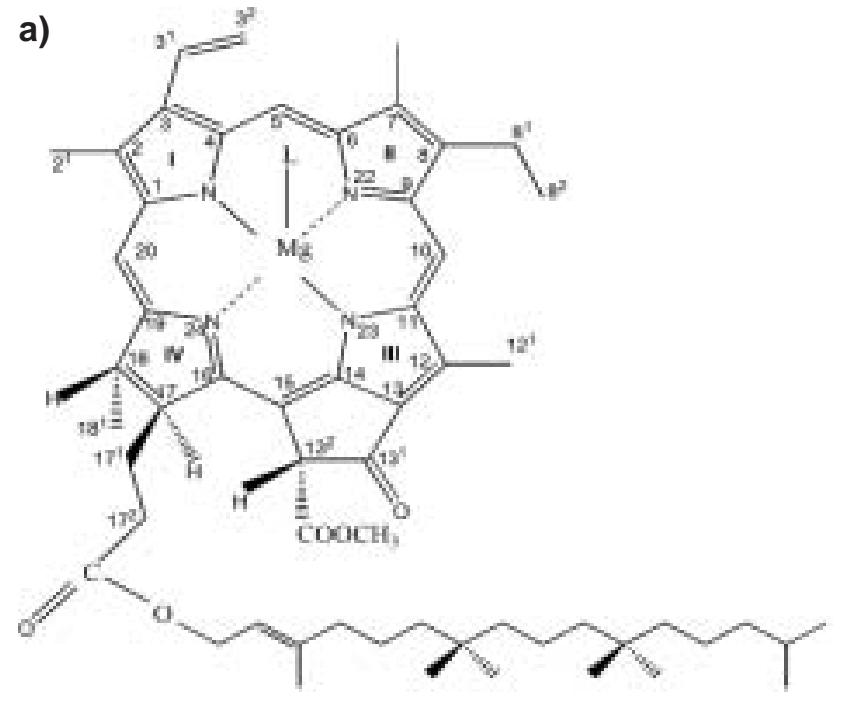

c)

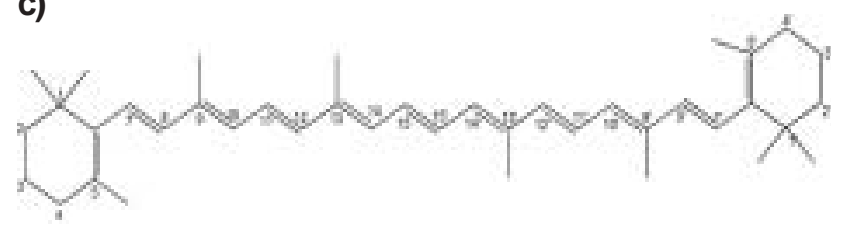

b)

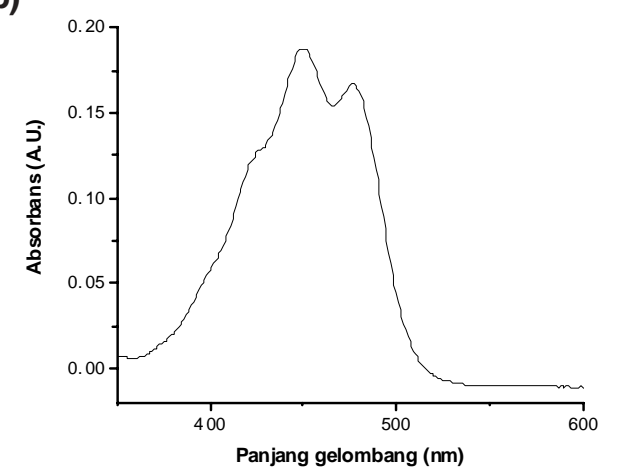

d)

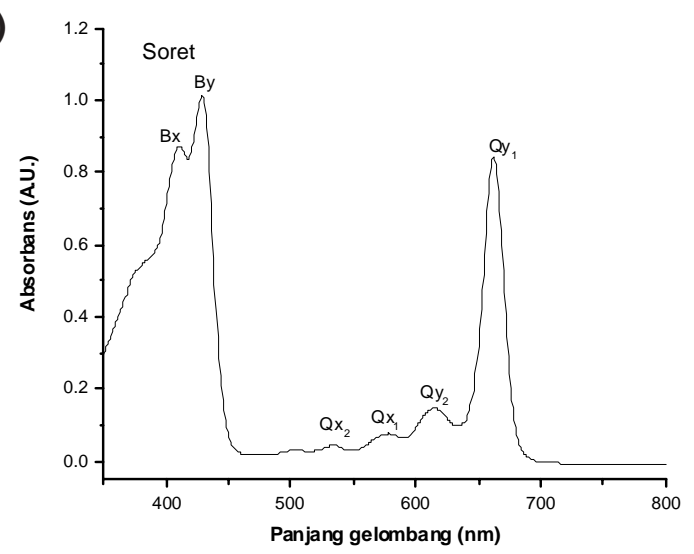

Gambar 1. Struktur molekul dan pola spektrum klorofil a (a, b) dan beta karoten (c, d) dalam pelarut aseton

menggunakan filter merah RG 630 (Schott, ë e" 630 $\mathrm{nm}$ ) berintensitas 5140 lux. Iradiasi dilakukan dalam seri waktu 0, 0.5, 1, 2.5, 5, 10, 20, 30, 40, 50, 60 menit. Absorbansi dan pola spektra setiap larutan diukur sebelum dan setelah diiradiasi menggunakan spektrofotometer berkas rangkap Varian Cary 50 pada panjang gelombang 350-800 nm. Perlakuan yang sama dilakukan terhadap campuran klorofil $a$ dan beta karoten dengan perbandingan mol 1:1 dalam aseton.

Analisa Data. Data yang diperoleh dianalisis menggunakan Matlab 6.5 dan Origin 6.1 secara deskriptif.

\section{HASIL DAN PEMBAHASAN}

Agregasi klorofil $a$ sebagai bentuk pertahanan diri terhadap energi cahaya yang berlebihan. Proses fotosintesis dimulai ketika suatu foton cahaya matahari ditangkap oleh klorofil $a$ sebagai pigmen utama pada antena penangkap cahaya (light harvesting, LH), disamping pigmen lain seperti klorofil $b$ maupun karotenoid. Energi cahaya yang diserap pigmen mengeksitasi elektron-elektron dari tahapan dasar ke tahapan eksitasi, kemudian mentransfer energi tersebut ke klorofil atau pusat reaksi untuk diubah menjadi energi kimia. Transisi elektron dari tahapan dasar ke tahapan eksitasi setiap pigmen berbeda-beda sesuai dengan besar kecilnya energi cahaya yang diserap, struktur molekul, dan tahapan eksitasi elektronnya. Hal ini menyebabkan pola spektra setiap pigmen berbeda satu dengan yang lain. Struktur molekul dan pola spektra klorofil $a$ dan beta karoten disajikan pada Gambar 1a-d.

Organisme fotosintetik sering dihadapkan pada kondisi ekstrim dimana cahaya dengan energi yang besar secara terus-menerus mengenainya. Salah satu strategi klorofil $a$ untuk bertahan dalam kondisi dimana energi cahaya yang mengenainya berlebihan adalah dengan melakukan agregasi (Katz et al, 1978a; Scherz et al, 1991 cit Scheer 2006). Strategi yang dilakukan dengan membentuk agregasi antar molekul klorofil sendiri atau dengan molekul-molekul yang lain, seperti karotenoid dan protein membentuk interaksi pigmenpigmen maupun pigmen-protein yang menghasilkan efisiensi transfer energi cahaya yang luar biasa untuk diubah menjadi energi kimia. 
Bagian-bagian dari struktur molekul klorofil memiliki karakteristik yang sangat penting untuk proses organisasi. Pusat logam makrosiklik klorofil menyediakan lokasi ikatan dengan elektron donor nukleufilik, grup karbonil pada C-13 $3^{3}$ dan $\mathrm{C}-17^{3}$ bertindak sebagai pendonor elektron nukleufilik, grup alkil pada posisi 3, 7, 8, dan grup 173-ester (Gambar 1a) terutama untuk hidrofobisitas molekul dan interaksi-interaksi khusus dalam agregasi klorofil (Agostiano et al, 2003).

Agregasi antar molekul klorofil bisa terjadi dalam pelarut yang mengandung air (Vladkova 2000). Penambahan air yang dilakukan pada berbagai konsentrasi dalam studi ini menunjukkan pengaruh yang bervariasi terhadap fotostabilitas klorofil $a$ selama dilakukan iradiasi dengan sinar merah (ë e" $630 \mathrm{~nm}$ ) (Gambar 2a-j). Penambahan air pada larutan klorofil $a$ dalam pelarut aseton, menimbulkan penurunan absorbansi klorofil $a$ pada spektrum serapnya, baik puncak $Q_{y}, Q_{x}$ maupun Soret seiring dengan bertambahnya prosentase air yang ditambahkan, sedangkan munculnya puncak baru yang semakin meningkat dengan bertambahnya volume air yang ditambahkan ke sampel pada daerah 970-979 nm diindikasi sebagai puncak serapan air.

Spektrum klorofil $a$ yang ditambah dengan berbagai volume air mengalami pergeseran batokromik. Puncakpuncak serapan $\mathrm{Q}_{\mathrm{y}}$ klorofil $a$ bergeser ke daerah merah dari $\sim 1 \mathrm{~nm}$ hingga $\sim 9 \mathrm{~nm}(663.1-672 \mathrm{~nm})$ setelah penambahan air 8.33- $66.6 \%$ sebelum dilakukan iradiasi dan $13 \mathrm{~nm}$ (663.1-676 nm) setelah 60 menit diiradiasi (Gambar 2a-h). Sedangkan spektrum klorofil $a$ dengan konsentrasi air $>66.67 \%$, meskipun puncak $Q_{y}$-nya tetap bergeser ke daerah merah, tetapi pergeserannya lebih pendek, yakni 7-8 nm sebelum dan setelah diiradiasi (Gambar 2i-j).

Pergeseran $Q_{y}$ klorofil $a$ ke daerah merah ketika larutan klorofil $a$ ditambahkan air menunjukkan adanya agregasi yang terbentuk oleh perantara air sebagai pendonor elektron, apakah itu dalam bentuk dimer, trimer maupun oligomerik. Asumsi ini sesuai dengan yang dilaporkan oleh de Paula et al, (1995), bahwa agregasi porfirin dan klorofil dalam larutan mempengaruhi struktur elektron pada makrosiklik, dimana perubahan struktur elektron pada makrosiklik akibat agregasi ini menyebabkan adanya perubahan pita absorpsi dan mengalami pergeseran ke daerah panjang gelombang yang lebih besar (Goedheer 1966;
Agostiano et al, 2003). Goedheer (1966) juga menyatakan bahwa interaksi molekul klorofil dengan molekul-molekul pigmen lain mempengaruhi bentuk dan posisi pita absorbansi, yang biasanya menjadi lebih lebar dan mengalami pergeseran ke daerah merah.

Berdasarkan pola spektrum klorofil $a$ dengan berbagai konsentrasi air yang ditunjukkan pada Gambar 2, tampak muncul puncak baru pada spektrum klorofil $a$ yang konsentrasi air dalam larutan d" $25 \%$, yaitu pada daerah 750-753 nm (8.33\%), $754 \mathrm{~nm}$ (16.67\%) dan 755 nm (25\%) (Gambar 2a-c). Puncak serapan ini menunjukkan serapan bentuk oligomerik agregat klorofil (Agostiano et al, 2003; Vladkova 2000), sedangkan pergeseran serapan $Q_{y}$ klorofil $a$ dari 663,1 s.d. $670 \mathrm{~nm}$ pada larutan klorofil $a$ dengan kandungan air e" $50 \%$, menunjukkan adanya serapan campuran monomer dan dimer klorofil $a$ karena ikatan-ikatan oligomerik yang mulai terputus menjadi dimer dan monomer klorofil $a$ (Agostiano et al, 2003) (Gambar 2f-j). Adanya serapan bentuk agregat oligomerik klorofil $a$ pada daerah 750$753 \mathrm{~nm}$ yang terdeteksi selama 10-20 menit, mempengaruhi proses degradasi pigmen klorofil $a$, dimana meskipun mengalami degradasi, klorofil $a$ belum terdegradasi sebagian selama serapan bentuk oligomerik ini muncul. Dengan demikian, agregasi yang terbentuk dengan perantara molekul air (Vladkova 2000) digunakan molekul klorofil untuk bertahan selama iradiasi berlangsung (Katz et al, 1978a; Scherz et al, 1991 cit Scheer 2006), nyata terlihat. Namun, bentuk agregat oligomerik yang terbentuk tidak dapat bertahan lama. Pada saat penyinaran dilakukan lebih lama (di atas 20 menit), ikatan antar molekul klorofil $a$ terlepas, menyebabkan klorofil tidak dapat bertahan dan akhirnya rusak yang ditemukan hingga $88.27 \%$ setelah 60 menit iradiasi (Tabel 1).

\section{Pengaruh Agregasi Klorofil a dan Paduannya} Dengan Beta Karoten Dalam Fotodegradasi Klorofil $a$. Perlindungan terhadap klorofil $a$ pada kondisi cahaya yang berlebihan juga dilakukan oleh pigmen karotenoid (Zurdo et al, 1992; Porra et al, 1997; Barzda et al, 1998; Wang et al, 2004; Standfuss et al, 2005). Kombinasi agregasi dan beta karoten sekaligus dalam fotodegradasi klorofil $a$ juga diamati dalam studi ini yang ditunjukkan pada Gambar 3a-j. Seperti spektrum klorofil $a$, puncak-puncak $\mathrm{Q}_{\mathrm{y}}, \mathrm{Q}_{\mathrm{x}}$, dan Soret pada spektrum campuran klorofil $a$ dan beta karoten juga mengalami penurunan absorbansi seiring dengan bertambahnya 

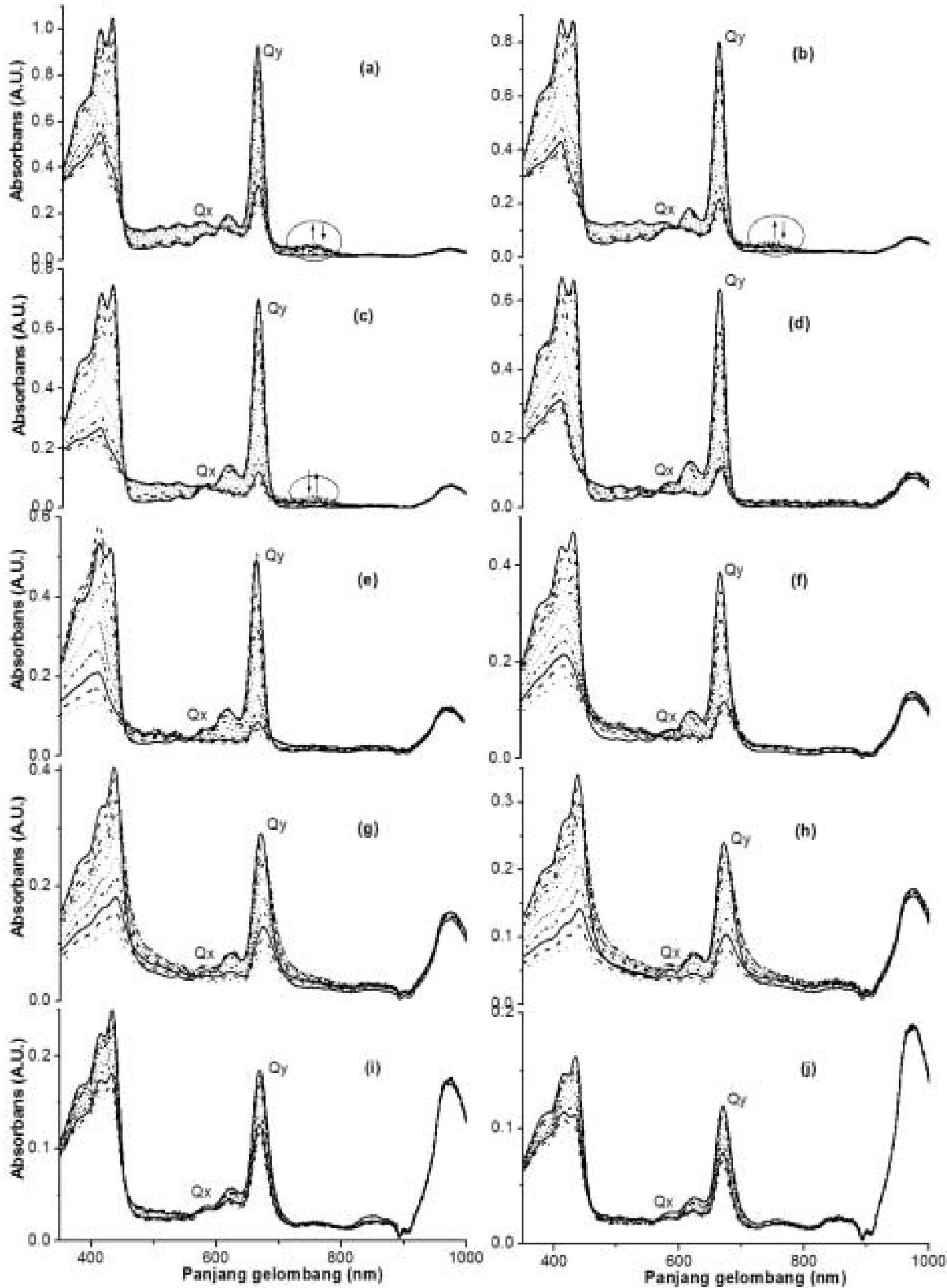

Gambar 2. Pola spektra klorofil a dalam pelarut aseton dengan penambahan akuades masing-masing $0.25 \mathrm{~mL}(8.33 \%)(\mathrm{a}) ; 0.50 \mathrm{~mL}$ (16.67\%) (b); $0.75 \mathrm{~mL}(25 \%)$ (c); $1.00 \mathrm{~mL}$ (33.33\%) (d); $1.25 \mathrm{~mL}(41.67 \%)$ (e); $1.50 \mathrm{~mL}(50 \%)$ (f); $1.75 \mathrm{~mL}(58.33 \%)(\mathrm{g})$; $2.00 \mathrm{~mL}(66.67 \%)(\mathrm{h}) ; 2.25 \mathrm{~mL}$ (75\%) (i); $2.50 \mathrm{~mL}$ (83.33\%) (j) selama diradiasi dengan sinar merah (ë e" $630 \mathrm{~nm}$ ) pada menit ke: 0 menit $\longleftarrow$ ); 0.5 menit $(\quad)$; 1 menit $(\ldots)$ ); 2.5 menit $(\quad)$; 5 menit $(\quad)$; 10 menit $(\quad) ; 20$ menit (........); 30 menit $(\quad$ ); 40 menit $(\quad$ ); 50 menit $(\quad)$; dan 60 menit ( . . . .). 
Gambar 3. Pola spektra klorofil a yang dicampur dengan beta karoten dalam pelarut aseton dengan penambahan akuades masingmasing $0.25 \mathrm{~mL}$ (8.33\%) (a); $0.50 \mathrm{~mL}$ (16.67\%) (b); $0.75 \mathrm{~mL}$ (25\%) (c); $1.00 \mathrm{~mL}$ (33.33\%) (d); $1.25 \mathrm{~mL}(41.67 \%)(\mathrm{e}) ; 1.50$ $\mathrm{mL}(50 \%)(\mathrm{f}) ; 1.75 \mathrm{~mL}(58.33 \%)(\mathrm{g}) ; 2.00 \mathrm{~mL}(66.67 \%)(\mathrm{h}) ; 2.25 \mathrm{~mL}$ (75\%) (i); $2.50 \mathrm{~mL}$ (83.33\%) (j) selama diiradiasi dengan sinar merah (ë e" $630 \mathrm{~nm}$ ) pada menit ke: 0 menit (__ ); 0.5 menit ( _ ); 1 menit (...);2.5 menit ( ) ); 5 menit ( );10 menit ( ) );20 menit (........);30 menit ( );40 menit ( );50 menit ( ); dan 60 menit $(\ldots .$.$) .$ 
Tabel 1. Prosentase peluruhan $\mathrm{Q}_{\mathrm{y}}$ klorofil $a$ (.) dan campuran klorofil $a$ dengan beta karoten (..) dalam pelarut aseton dengan penambahan air dalam berbagai konsentrasi

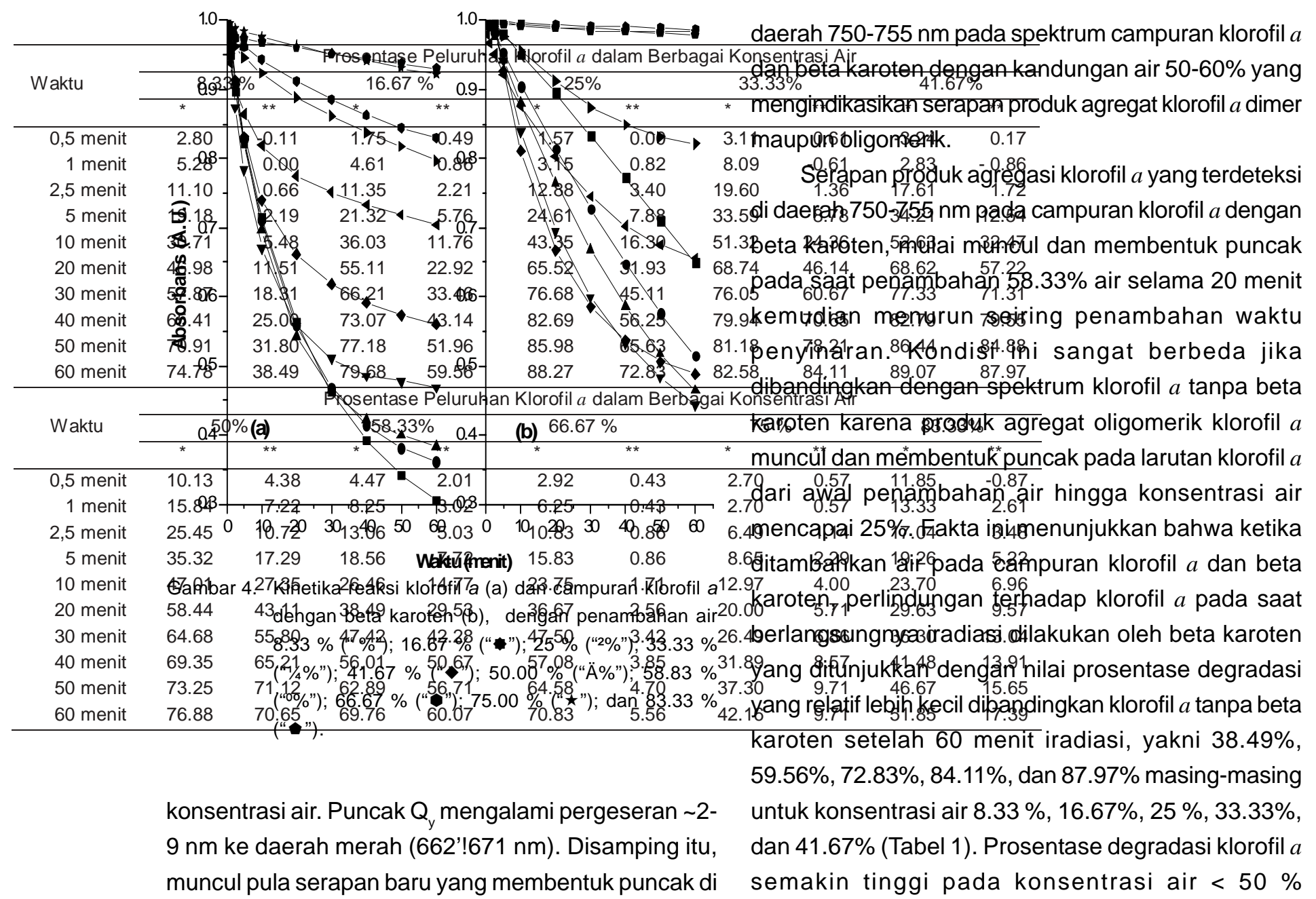


Tabel 2. Pola peluruhan (Orde), laju reaksi fotodegradasi (k), dan waktu paruh $\left(\mathrm{t}_{1 / 2}\right)$ klorofil $a\left({ }_{*}\right)$ dan campuran klorofil $a$ dengan beta karoten (..) pada berbagai konsentrasi air

\begin{tabular}{|c|c|c|c|c|}
\hline \multirow{3}{*}{ Parameter } & \multicolumn{4}{|c|}{ Kandungan Air dalam Larutan } \\
\hline & \multicolumn{2}{|c|}{$8.33 \%$} & \multicolumn{2}{|c|}{$16.67 \%$} \\
\hline & * & ** & * & ** \\
\hline Orde & 1.838 & $2.377 e^{-0015}$ & 1.753 & 0.555 \\
\hline 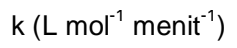 & 0.045 & 0.006 & 0.065 & 0.011 \\
\hline \multirow[t]{2}{*}{$t_{1 / 2}$ (menit) } & 21.586 & 71.034 & 15.895 & 47.639 \\
\hline & \multicolumn{4}{|c|}{ Kandungan Air dalam Larutan } \\
\hline \multirow[t]{2}{*}{ Parameter } & \multicolumn{2}{|c|}{$25 \%$} & \multicolumn{2}{|c|}{$33.33 \%$} \\
\hline & * & ** & * & ** \\
\hline Orde & 1.455 & 0.737 & 2.064 & 0.957 \\
\hline $\mathrm{k}\left(\mathrm{L} \mathrm{mol}^{-1}\right.$ menit $\left.^{-1}\right)$ & 0.079 & 0.017 & 0.180 & 0.030 \\
\hline \multirow[t]{2}{*}{$t_{1 / 2}$ (menit) } & 14.394 & 32.920 & 9.377 & 22.206 \\
\hline & \multicolumn{4}{|c|}{ Kandungan Air dalam Larutan } \\
\hline \multirow[t]{2}{*}{ Parameter } & \multicolumn{2}{|c|}{$41.67 \%$} & \multicolumn{2}{|c|}{$50 \%$} \\
\hline & * & ** & * & ** \\
\hline Orde & 1.831 & 1.084 & 3.231 & 1.437 \\
\hline $\mathrm{k}\left(\mathrm{L} \mathrm{mol}^{-1}\right.$ menit $\left.^{-1}\right)$ & 0.185 & 0.045 & 1.245 & 0.045 \\
\hline \multirow[t]{2}{*}{$\mathrm{t}_{1 / 2}$ (menit) } & 8.767 & 16.952 & - & 27.730 \\
\hline & \multicolumn{4}{|c|}{ Kandungan Air dalam Larutan } \\
\hline \multirow[t]{2}{*}{ Parameter } & \multicolumn{2}{|c|}{$58.33 \%$} & \multicolumn{2}{|c|}{$66.67 \%$} \\
\hline & * & ** & * & ** \\
\hline Orde & 1.787 & 1.321 & 1.358 & 3.645 \\
\hline 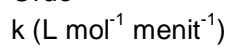 & 0.0768 & 0.028 & 0.041 & 1.287 \\
\hline \multirow[t]{2}{*}{$t_{1 / 2}$ (menit) } & 31.054 & 41.674 & 34.027 & \\
\hline & \multicolumn{4}{|c|}{ Kandungan Air dalam Larutan } \\
\hline \multirow[t]{2}{*}{ Parameter } & \multicolumn{2}{|c|}{$75 \%$} & \multicolumn{2}{|c|}{$83.33 \%$} \\
\hline & * & ** & * & ** \\
\hline Orde & 2.222 & 4.058 & 3.582 & 3.645 \\
\hline $\mathrm{k}\left(\mathrm{L} \mathrm{mol}^{-1}\right.$ menit $\left.^{-1}\right)$ & 0.096 & 0.045 & 0.066 & 1.287 \\
\hline $\mathrm{t}_{1 / 2}$ (menit) & 86.703 & - & - & \\
\hline
\end{tabular}

menunjukkan ketidakmampuan beta karoten untuk melindungi lebih lanjut karena beta karoten ikut terdegradasi (Gambar 3a-f), tetapi prosentase degradasi klorofil a mulai menurun pada saat konsentrasi air lebih dari 50\%. Penurunan prosentase degradasi klorofil $a$ terjadi karena pada saat konsentrasi air dalam campuran klorofil $a$ dan beta karoten diatas $50 \%$, berhasil memediasi proses agregasi antar molekul klorofil $a$ yang terdeteksi pada spektrum dan membentuk puncak pada saat konsentrasi air mencapai $58.33 \%$ sehingga energi yang berlebihan dapat dilepaskan melalui rangkaian agregasi molekul klorofil $a$ yang terbentuk.

Kombinasi peran beta karoten dan agregasi terlihat nyata pada saat konsentrasi air mencapai $66.67 \%$. $Q_{y}$ klorofil $a$ yang dicampur dengan beta karoten hanya meluruh 5.56\% setelah 60 menit iradiasi. Sedangkan prosentase peluruhan $\mathrm{Q}_{\mathrm{y}}$ klorofil $a$ tanpa beta karoten pada kandungan air yang sama (66.67\%), mencapai $70.83 \%$ setelah diiradiasi dengan durasi waktu dan intensitas sinar yang sama. Prosentase degradasi klorofil $a$ pada campuran klorofil $a$ dan beta karoten tanpa penambahan air pun tidak lebih kecil dari 5.56\% yakni $12.14 \%$ (da Costa et al, 2007). Dengan demikian, pada saat konsentrasi air dalam larutan sebanyak $66.67 \%$, klorofil $a$ sama-sama mendapat perlindungan dari beta karoten dan agregasi, yang terbentuk selama iradiasi berlangsung karena pada pola spektrumnya terdeteksi bentuk agregat oligomer pada daerah 849 - 855 nm (Gambar 3h).

Pengaruh beta karoten terhadap fotostabilitas klorofil $a$ lebih jelas terlihat pada orde reaksi, kecepatan peluruhan dan waktu paruh klorofil $a$ atau campuran klorofil $a$ dengan beta karoten dalam volume air yang berbeda-beda yang ditunjukkan pada Tabel 2 . Peluruhan klorofil $a$ pada setiap penambahan volume air mengikuti orde yang bervariasi antara 1 sampai 3 , dimana semakin besar kandungan air, semakin stabil klorofil $a$ (Gambar 4a). Waktu paruh yang dibutuhkan oleh klorofil $a$ untuk meluruh sebagian tercatat kurang dari 35 menit untuk semua konsentrasi air kecuali pada konsentrasi $75 \%$ karena membutuhkan waktu yang lebih lama yakni 86.7 menit (Tabel 2). Sedangkan peluruhan absorbansi $Q_{y}$ pada campuran klorofil $a$ dan beta karoten mengikuti orde antara 0 hingga 4 (Gambar 4b) dengan kecepatan peluruhan dan waktu paruh yang bervariasi. Beberapa data waktu paruh terutama untuk orde reaksi 3 dan 4 tidak dapat ditampilkan, padahal peluruhan $Q_{y}$ yang mengikuti orde ini terlihat pada campuran klorofil $a$ dengan beta karoten yang memiliki prosentase peluruhan paling rendah (Tabel 1 dan 2). Dengan demikian, tidak diketahui waktu yang dibutuhkan klorofil $a$ dalam campurannya dengan beta karoten untuk meluruh sebagian dari konsentrasi semula pada larutan yang mengandung $66.67 \%, 75 \%$ dan $83.33 \%$ air.

Berdasarkan kinetika reaksi klorofil $a$ dengan dan tanpa beta karoten yang ditunjukkan pada Gambar 4, sangat nyata terlihat peran beta karoten dalam fotoproteksi klorofil $a$ dari fotodegradasi. Dengan hadirnya beta karoten, klorofil $a$ tidak menampakan kerusakan yang besar seperti tanpa beta karoten yang ditunjukkan ole.h nilai absorbansi $Q_{y}$ yang lebih tinggi (0.444 A. $\mathrm{U}^{-1}$ menit $^{-1}$ ) dibandingkan klorofil tanpa beta karoten (0306 A. $U^{-1}$ menit $\left.^{-1}\right)$ setelah akhir penyinaran. 


\section{KESIMPULAN}

Kendati sama-sama bertujuan untuk melindungi klorofil $a$ dari kerusakan akibat cahaya yang berlebihan, bentuk agregat klorofil a yang terbentuk dengan perantaraan molekul air, tidak dapat mempertahankan ikatan antar molekul klorofil $a$ untuk waktu yang lama. Masa hidup bentuk agregat oligomerik klorofil $a$ hanya 20 menit. Beta karoten ditemukan memiliki kemampuan fotoproteksi yang baik terhadap klorofil $a$. Dengan kombinasi beta karoten dan air yang memediasi pembentukan agregasi sebanyak $66.67 \%$, klorofil $a$ hanya terdegradasi $5.56 \%$ setelah 60 menit diiradiasi. Jadi, kombinasi beta karoten dan bentuk agregat klorofil a sama-sama menunjukkan perlindungan yang luar biasa terhadap klorofil $a$ dibandingkan campuran klorofil $a$ dan beta karoten tanpa molekul air.

\section{UCAPAN TERIMAKASIH}

Penulis mengucapkan terima kasih atas dukungan Beasiswa Unggulan Depdiknas RI tahun 2006 kepada Junet F. da Costa. Sebagian dari dana penelitian ini diperoleh L. Limantara dari TWAS, Italia.

\section{DAFTAR PUSTAKA}

Abeliovich, A. \& Shilo, M. 1972. Photoxidative death in bluegreen algae. J. Bacteriol 111: 682-689.

Agostiano, A., Catucci, L. Cosma, P. \& Fini, P. 2003. Aggregation processes and photophysical properties of chlorophyll $a$ in aqueous solution modulated by presence of cyclodextrins. Phys. Chem. 5: 2122-2128.

Anderson, A. F. H., \& Calvin, M. 1964. The aggregation of chlorophyll $a$. Archives of biochemistry and biophysics 107: 251-259.

Barzda, V., Peterman, E. J. G., Van Grondelle, R. \& Van Amerongen, H. 1998. The Influence of aggregation on triplet formation in light-harvesting chlorophyll $a / b$ pigment-protein complex II of green plants. Biochem 37: 546-551.

Brandis, A. S, Salomon, Y. \& Scherz, A. 2006. Chlorophyll sensitizer in photodynamic therapy. Di dalam: Grimm, B. Porra, R. Rüdiger, W. \& Scheer, H (ed). Chlorophyll and Bacteriochlorophyll: Biochemistry, Biophysic, Function and Apllications. Netherlands: Springer.

Britton, G., Liaaen-Jensen, S. \& Pfander, H. 1995. Carotenoids Today and Challenges for The Future. Di dalam: Britton, G. Liaaen-Jensen, S. \& Pfander, H. (ed). Isolation and Analysis. Vol.IA. Birkhäuser Verlag Basel.
Efek beta karoten dan agregasi klorofil

da Costa, J. F., Karwur, F. F. \& Limantara, L. 2007. Fotoproteksi Beta Karoten dan Lutein Terhadap Klorofil $a$ dalam Aseton. Prosiding Seminar Pigmen Nasional 2007 Back To Nature Dengan Pigmen Alami. Salatiga, 24 Agustus 2007.

de Paula, J. C., Robblee, J. H. \& Pasternackt, R. F. 1995. Aggregation of chlorophyll $a$ probed byresonance light scattering spectroscopy. Biophys. J. 68: 335-341

Fiedor, J., Fiedor, L. Winkler, J. Scherz, A. \& Scheer, H. 2001. Photodynamic of the Bacteriochlorophyll-Carotenoid System 1. Bacteriochlorophyll-photosensitized oxygenation of Beta-Caroten in Aceton. Photochem. Photobiol 74: 6471.

Fiedor, J, Fiedor, L. Kammhuber, N. Scherz, A. \& Scheer, H. 2002. Photodynamics of the bacteriochlorophyll-carotenoid System. 2. Influence of central metal, solvent and beta carotene on photobleaching of bacteriochlorophyll derivatives. Photochem Photobiol 76: 145-152.

Gross, J. 1987. Pigments in Fruits. London: Kluwer Academic Publisher.

Gross, J.1991. Pigments in Vegetables: Chlorophyll and Carotenoids. New York: Van Nostrand Reinhold

Goedheer, J.C.1966. Visible Absorption and Flourescence of Chlorophyll and Its Aggregates in Solution. Di dalam: Vernon, L.P. \& Seely, G. R. A. (ed). The Chlorophyll. New York: Academic Press.

Jeffrey, S. W, Mantoura, R. F. C. \& Wright, S. W. 1997. Phytoplankton Pigments in Oceanography: Guidelines to Modern Methods. Paris: UNESCO

Katz, J.J., Shipman, L. L. Cotton, T.M. \& Janson, T.R. 1978a. Chlorophyll aggregation: Coordination interactions in chlorophyll monomers, dimers and oligomers. Di dalam: Dolphin, D. (ed). The Porphyrins. New York: Academic Press.

Katz, J.J, Norris, J. R. Shipman, L.L. Thurnauer, M. C. \& Wasielewski, M. R. 1978b. Chlorophyll function in the photosyntetic reaction center. Ann. Rev. Biophys. Bioeng 7:393-434

Lichtenthaler, K. H. 1987. Methods in Enzymology. Chlorophyll and Carotenoid: Pigments of Photosynthetic Biomembranes. New York: Academic Press.Inc.

Porra, R. J., Pfündel, E. E. \& Engel, N. 1997. Metabolism and function of photosyntesis. Di dalam: Jeffrey, S. W. Mantoura, R. F. C. \& Wright, S.W. (ed). Phytoplankton Pigments in Oceanography. France: UNESCO.

Scheer, H., 1991. Chlorophylls. USA: CRC Press, Inc.

Scheer, H. 2006. An overview of chlorophylls and bacteriochlorophylls: biochemistry, biophysics, function and apllications. Di dalam: Grimm, B., Porra, R. Rüdiger, W. \& Scheer, $\mathrm{H}$ (ed). Chlorophyll and Bacteriochlorophyll: Biochemistry, Biophysics, Function and Apllications. Netherlands: Springer.

Standfuss, J., Van Scheltinga, A. C. T. Lamborghini, M. \& Kühlbrandt, W. 2005. Mechanisms of Photoprotection and Nonphotochemical Quenching in Pea Light harvesting Complex at 2.5^ resolution. The EMBO journal 24:919-928.

Vladkova, R., 2000. Chlorophyll $a$ Self-assembly in Polar SolventWater Mixtures. Photochem Photobiol 71: 71-83

Wang, Y., Mao, L. \& Hu, X. 2004. Insight into the structural role of carotenoids in photosystem I: A quantum chemical analysis. Biophys J. 86: 3097-3111.

Zurdo, J., Fernández-Cabrera, C. \& Ramírez, J.M. 1992. Enhancement of carotenoid-to-chlorophyll singlet energy transfer by carotenoid-carotenoid interaction. Biophys. J. 61: 1462-1469. 